\title{
PEPTIDES IN HUMAN NUTRITION
}

\author{
GEORGE K. GRIMBLE AND DAVID B. A. SILK
}

Department of Gastroenterology \& Nutrition, Central Middlesex Hospital, Acton Lane, London NW10 7NS

\section{CONTENTS}

INTRODUCTION

APPLICATION OF PEPTIDES TO ORAL NUTRITION . . . . . . . 88

QUALITATIVE ASPECTS OF DIETARY PROTEIN ASSIMILATION . . . $\quad 88$

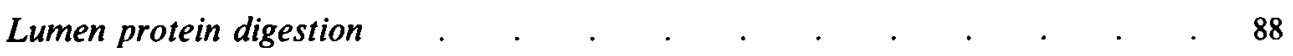

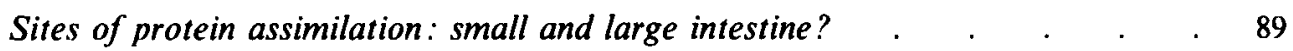

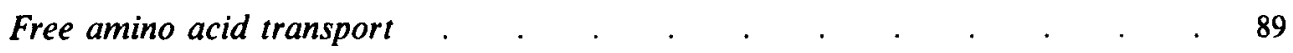

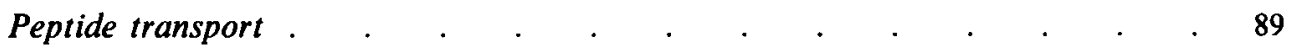

QUANTITATIVE ASPECTS OF DIETARY PROTEIN ASSIMILATION . . . $\quad 90$

Perfusion studies . . . . . . . . . . . . . . . . . . . . . 90

Anïmal feeding studies . $\quad . \quad$.

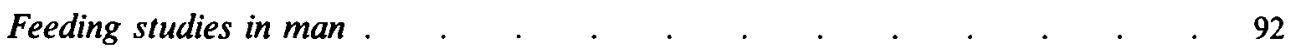

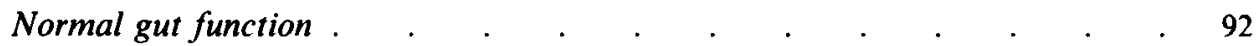

Impaired gut function $\quad . \quad$.

CONCLUSIONS AND PERSPECTIVES . . . . . . . . . . . . . . . 92

APPLICATION OF PEPTIDES TO INTRAVENOUS NUTRITION . . 93

EVIDENCE FOR ENDOGENOUS HYDROLYSIS OF CIRCULATING PEPTIDES . 93

TRANSLOCATION OF PEPTIDES ACROSS THE GASTROINTESTINAL BARRIER 93

THE ROLE OF THE KIDNEY IN DISPOSAL OF CIRCULATING PEPTIDES . • 93

INFUSION STUDIES WITH SYNTHETIC DIPEPTIDES . . . . . . . . . . 94

LARGE-SCALE USE OF INTRAVENOUS PROTEIN HYDROLYSATES . . . 95

Comparison with free amino acids. . . . . . . . . . . . . . . . . 95

Peptiduria . . . . . . . . . . . . . . . . . . . 96

THE RATIONALE FOR INTRAVENOUS PEPTIDES. . . . . . . . . . $\quad .97$

Synthetic peptides. . . . . . . . . . . . . . . . . . . . . $\quad .97$

$\begin{array}{ll}\text { Evidence for a role for glutamine in septic or traumatized patients . } & 97\end{array}$

Possible sources of glutamine for intravenous use . . . . . . . . . 97

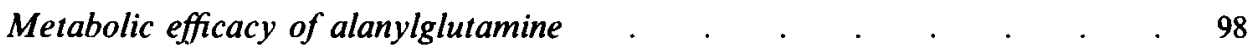

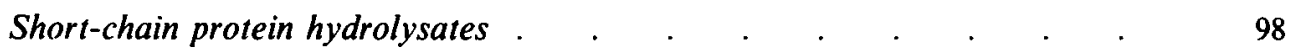

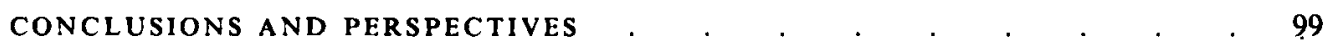

PRODUCTION OF SYNTHETIC DIPEPTIDES OR PROTEIN

SYNTHETIC DIPEPTIDES

PROTEIN HYDROLYSATES 
Amino acid adequacy . . . . . . . . . . . . . . . . . 100

Taste properties . . . . . . . . . . . . . . . . . 100

Peptide chain length . . . . . . . . . . . . . . . . 101

Glutamine content . . . . . . . . . . . . . . 101

Analysis. . . . . . . . . . . . . . . . . 101

CONCLUSIONS AND PERSPECTIVES . . . . . . . . . . . . . . 102

REFERENCES . . . . . . . . . . . . . . . . . . . 102

\section{INTRODUCTION}

At first sight, small peptides would appear not to play a significant role in human protein metabolism. The classical view is summarized by models describing the flux of free amino acids between plasma and tissue amino acid and protein pools. However, a large part of amino acid flux is as short-chain peptides. First, ingested protein $(70-100 \mathrm{~g} / \mathrm{d})$ is presented to the gut mucosa in the form of peptides with a chain length of two to six amino acids (Grimble \& Silk, 1986). A significant proportion of the amino acids released during tissue protein degradation $(200-300 \mathrm{~g} / \mathrm{d})$ is in the form of di- and tripeptides, which are subsequently hydrolysed to free amino acids within the intracellular compartment. This process is extremely rapid, and the existence of a peptide pool has been shown only by use of a specific peptidase inhibitor, bestatin (Botbol \& Scornik, 1983). Finally, the renal brush border, and to a lesser extent liver and muscle, appear to be the sites of extracellular hydrolysis of significant quantities of circulating peptides. These processes are relevant to the form in which nitrogen should be given to patients receiving nutritional support via the intravenous or nasoenteral routes. Thus, synthetic di- and tripeptides have been considered as a vehicle for amino acids which are themselves unstable or sparingly soluble. Considerable effort has also been expended in determining whether there is any need to predigest dietary protein to small peptides, in order to improve $\mathrm{N}$ absorption in patients with impaired gastrointestinal function. Finally, the problem of 'bitter peptide' release during partial enzymic hydrolysis of food proteins has also been investigated fully.

In the present review, advances in a number of different areas of peptide research will be discussed in order to answer the question 'Is there a place for peptides in clinical protein nutrition?'

\section{APPLICATION OF PEPTIDES TO ORAL NUTRITION}

Most manufacturers of liquid enteral diets produce some diets in which the protein has been partially hydrolysed or replaced with free amino acids. The rationale is that "predigestion' of the protein may improve $\mathrm{N}$ absorption in patients whose intestinal function is impaired through significant loss of absorptive surface (e.g. small bowel resection) or digestive function (e.g. following pancreatectomy). This section will briefly review the major mechanisms of uptake of protein amino acids. In addition, experimental evidence which suggests that peptide uptake in the small intestine may be of great nutritional significance will be described in detail.

\section{QUALITATIVE ASPECTS OF DIETARY PROTEIN ASSIMILATION}

\section{Lumen protein digestion}

Hydrolysis of proteins to small peptides and free amino acids occurs within the intestinal lumen (gastric, jejunal, ileal) and at the enterocyte brush border. Aspects of the enzymology 
and significance of luminal protein hydrolysis by gastric, pancreatic and solubilized brushborder peptidases is reviewed in some detail elsewhere (Gray \& Cooper, 1971; Freeman et al. 1983; Desnuelle, 1986; Puigserver et al. 1986; Grimble \& Silk, 1986).

\section{Sites of protein assimilation: small and large intestine?}

Assimilation of dietary protein occurs mainly in the proximal jejunum (Silk et al. 1979), although the ileum has considerable digestive and absorptive capacity (Chung et al. 1979). Animal studies (Curtis et al. 1978) have implicated the colon as the major site of assimilation of endogenously derived protein (intestinal secretions, secreted plasma proteins and desquamated cells). However, despite this, there is no quantitative information on the absorptive capacity of the normal human small bowel. Two indirect lines of evidence suggest that small, but significant, quantities of protein pass from the lumen of the ileum into the colon.

First, in patients with ileostomy (Chacko \& Cummings, 1988) $\mathrm{N}$ losses from the small bowel (mainly as protein and small peptides) have been shown to be significant (approximately 10-20\% of intake). The microflora of the large intestine are capable of digesting endogenous proteins (e.g. mucins) in vitro (Gibson et al. 1988a,b) and dietary proteins in vitro (MacFarlane \& Allison, 1986; MacFarlane et al. 1986) and in vivo (MacFarlane et al. 1986). Luminal hydrolysis of protein, to small peptides, occurs by the action of pancreatic enzymes and secreted and cell-wall bound bacterial peptidases. Peptide hydrolysis appears to be the rate-limiting step for subsequent fermentation of amino acids to short-chain fatty acids, dicarboxylic acids, phenolic compounds and ammonia, all of which may be absorbed or metabolized by the large intestine, (MacFarlane \& Allison, 1986; Grimble, 1989; Silk, 1989). There is, thus, the potential for salvage of the carbon and $\mathrm{N}$ moieties of protein malabsorbed by the small bowel which is not incorporated into faecal bacterial mass.

\section{Free amino acid transport}

There appear to be four major, group-specific, active transport systems in the mammalian enterocyte (Wellner \& Meister, 1981; Matthews \& Payne, 1980; Matthews, 1984): (1) monoamino, monocarboxylic (neutral amino acids), (2) glycine, proline, hydroxyproline, (3) dibasic amino acids and cysteine, (4) dicarboxylic (acidic) amino acids.

Further definition of these systems in the intact intestine is complicated by the presence of multiple transport systems within each group, and differing transport characteristics for the same amino acid, at the enterocyte brush border and basolateral membrane (see Burston \& Matthews, 1984; Matthews \& Burston, 1984b; Semenza \& Corcelli, 1986).

\section{Peptide transport}

The close connection between brush-border membrane hydrolysis of peptides and their uptake (Adibi, 1971; Matthews, 1975a; Silk et al. 1976; Nicholson \& Peters, 1978, 1979; Tobey et al. 1985) is consistent with a 'dual hypothesis' of peptide assimilation. In this scheme, a di- or tripeptide can be absorbed intact by a system which is distinct from any amino acid transporter. Peptides which are absorbed intact are hydrolysed intracellularly. Alternatively, constituent amino acids or smaller peptide fragments may be absorbed after brush-border membrane hydrolysis of the peptide. The evidence for intact tetrapeptide uptake is conflicting and most studies have shown a requirement for prior brush-border hydrolysis (Silk, 1981; Grimble \& Silk 1986, 1989).

The strong relationship between hydrophobicity and affinity for transport of the neutral amino acids does not hold when they are presented to the luminal mucosa in the form of homologous dipeptides (Burston et al. 1982; Matthews \& Burston, 1983). Indeed, it is hard 
to discern any strong structure-activity relationship for intact di- and tripeptide transport. Thus, it is still not clear whether there is one peptide carrier of broad specificity whose activity may be allosterically modified by the more hydrophobic peptides (Matthews \& Burston, 1984a), or whether there are multiple carriers (Rubino et al. 1971). Microelectrode and brush-border membrane vesicle studies have shown that dipeptide uptake is 'driven' by a hydrogen ion, not a sodium ion gradient (Boyd \& Ward, 1982; Ganapathy et al. 1981, 1984; Ganapathy \& Leibach, 1983, 1985; Rajendran et al. 1985).

\section{QUANTITATIVE ASPECTS OF DIETARY PROTEIN ASSIMILATION}

\section{Perfusion studies}

Studies in young animals have suggested that dipeptide transport is of greater quantitative significance than free amino acid transport during early growth (Guandalini \& Rubino, 1982; Miller et al. 1984). Likewise in human intestinal perfusion studies di- and tripeptide uptake was inhibited less than free amino acid uptake following 2 weeks of starvation (Vasquez et al. 1985). In a number of human and animal meal-feeding and intestinal-perfusion studies, the rate of absorption of individual amino acid residues was faster and more even from partially hydrolysed protein (containing most amino acids in peptide form) than from its equivalent free amino acid mixture (Fairclough et al. 1980; Silk et al. 1980; Grimble et al. 1986; Rerat et al. 1988). These findings suggest that there may be an absorptive advantage in using protein hydrolysates rather than free amino acids in enteral diets.

This issue is contentious, and the so-called 'kinetic advantage' may be an artefact of the steady-state perfusion model. It has been argued that amino acid transport saturates at lower concentrations than dipeptide transport, such that uptake during perfusion at 100 mmol $\alpha$-amino $\left(\mathrm{NH}_{2}\right)-\mathrm{N} / 1$ would occur under saturating and non-saturating conditions respectively for amino acids and peptides. This situation may be reversed at lower concentrations (Hegarty et al. 1982) and since during continuous nasoenteral nutrition the rate of infusion of amino acids (approximately $400 \mu \mathrm{mol} / \mathrm{min}$ ) is similar to that during intestinal perfusion at $30-40 \mathrm{mmol} \alpha-\mathrm{NH}_{2}-\mathrm{N} / \mathrm{l}$ (approximately $470 \mu \mathrm{mol} / \mathrm{min}$ ), there may be no absorptive advantage for protein hydrolysates over free amino acids. However, other factors also affect uptake. The starter protein, the method of enzymic hydrolysis and the chain length of constituent peptides have all been shown to alter uptake of amino acid residues from a number of protein hydrolysates (Silk et al. 1980; Keohane et al. 1985). Large alterations in the average peptide chain length of lactalbumin hydrolysates markedly affected uptake of amino acid residues (Grimble et al. 1986). A small increase in the chain length of ovalbumin and casein hydrolysates from di- and tripeptides to tetra- and pentapeptides (Table 1) markedly reduced $\mathbf{N}$ uptake from these preparations, at both high and low perfused concentrations (Grimble et al. 1987; Rees et al. 1988c). As in previous animal studies (Adibi \& Morse, 1977; Smithson \& Gray, 1977; Burston et al. 1979) it appears that in the absence of luminal pancreatic enzymes, brush-border hydrolysis of tetra- and pentapeptides is rate-limiting in the uptake of constituent $N$. Since the hydrolysate studied by Hegarty et al. (1982) contained predominantly medium-chain peptides it is possible that if a short-chain lactalbumin hydrolysate had also been studied a different conclusion might have been drawn.

The effect of the other hydrolysis variables on uptake have not been studied in such detail. Peptide sequence may influence uptake. Thus, if two hydrolysates of identical chainlength profile were produced from the same protein by two groups of peptidases with different bond specificity, this would markedly affect the sequence and hydrophobicity of 
Table 1. Effect of enzyme digestion method on peptide chain length of protein hydrolysates and jejunal absorption

\begin{tabular}{|c|c|c|c|c|c|c|c|c|c|}
\hline \multirow{3}{*}{$\begin{array}{c}\text { Hydrolysate } \\
\text { no. }\end{array}$} & \multirow{3}{*}{$\begin{array}{l}\text { Starter } \\
\text { protein }\end{array}$} & \multirow{3}{*}{$\begin{array}{l}\text { Enzyme } \\
\text { addition }\end{array}$} & \multirow{3}{*}{$\begin{array}{l}\text { Hydrolysate } \\
\text { type }\end{array}$} & \multicolumn{4}{|c|}{$\begin{array}{l}\text { Peptide chain length } \S \\
\mathrm{g} / 100 \mathrm{~g}\end{array}$} & \multirow{2}{*}{\multicolumn{2}{|c|}{$\begin{array}{c}\text { Jejunal absorption } \\
\text { at } 100 \mathrm{mmol} / 1 \\
\text { (\% absorption) }\end{array}$}} \\
\hline & & & & & & & Amino & & \\
\hline & & & & $>5$ & $4-5$ & $2-3$ & acids & Mean & Range \\
\hline 1 & Ovalbumin $\dagger$ & Sequential & Short-chain & Trace & 16 & 75 & 9 & $33 \cdot 6^{*}$ & $26 \cdot 4-40 \cdot 3$ \\
\hline 2 & Ovalbumin $\dagger$ & Sequential & $\begin{array}{l}\text { Medium- } \\
\text { chain }\end{array}$ & Trace & 68 & 24 & 8 & $23 \cdot 0^{*}$ & $13 \cdot 1-29 \cdot 3$ \\
\hline 3 & Casein $\ddagger$ & Sequential & Short-chain & Trace & 22.5 & 69.5 & 8 & $32 \cdot 0^{* *}$ & $7.6-47.5$ \\
\hline 4 & Casein $\ddagger$ & Sequential & $\begin{array}{l}\text { Medium- } \\
\text { chain }\end{array}$ & Trace & 64 & 35 & l & $24 \cdot 5^{* *}$ & $8 \cdot 8-29 \cdot 9$ \\
\hline
\end{tabular}

$\dagger$ Grimble et al. (1987).

$\ddagger$ Rees et al. $(1988 c)$.

$\S$ Chain length determined by Cu(n)-Sephadex method of Rothenbühler et al. (1979).

Mean values were significantly different (assessed by the randomization test for matched pairs): $P<0.05$, ** $P<0.02$.

constituent peptides in these two hypothetical mixtures. It would be of interest to determine if this had such marked effects on absorption of $\mathrm{N}$ and amino acids as does chain length. This would clearly be an area for fruitful investigation.

\section{Animal feeding studies}

A number of studies have examined the relative nutritional value of diets containing whole protein, partially digested protein or free amino acids. Only those which have been controlled for amino acid composition are discussed.

Diets based on casein or the identical amino acid mixture produce equal growth rates in young, healthy rats (Itoh et al. 1973). However, a whole-protein diet produced higher $\mathbf{N}$ retention, tissue weight and plasma protein levels in burned guinea-pigs than did the equivalent free amino acid diet (Trocki et al. 1986). These diets differed in one important respect. The amino acid diet was based on the amino acid composition of the protein, determined after complete acid hydrolysis, and no correction was apparently made for the loss of the carboxamide groups of asparagine and glutamine during acid hydrolysis. Since amide $\mathrm{N}$ can account for up to $20 \%$ of protein- $\mathrm{N}$, the composition of an 'equivalent' amino acid mixture has to be corrected, either by adding ammonium ions or the dicarboxylic acids with their amides in the ratio found in the native protein by sequence analysis. Both types of correction of the composition of a free amino acid diet were without effect on the growth rate of young rats (Itoh et al. 1973). Similarly, no difference was found in growth rates, food intake or the composition of peripheral tissues when rats received a hydrolysed whey protein diet or one of 'equivalent' (but uncorrected) amino acid composition (Grimble et al. 1989). What is surprising is that this small difference had such a marked effect on tissue $\mathbf{N}$ retention in burned animals. Provision of glutamine, not glutamate, in oral diets may be of importance during episodes of sepsis or trauma. Evidence reviewed by Windemueller (1982) suggests that the enterocyte can metabolize glutamine from luminal as well as arterial sources. The presence of glutamine in the small intestinal lumen of the rat has been shown to increase total enterocyte glutamine utilization, even though that from arterial sources was reduced. One would, thus, expect that glutamine supply to the small intestines of the two groups of burned animals was significantly 
different (Trocki et al. 1986) because of the subtle difference between the two diets. Oral supplementation with glutamine has been shown to reduced mortality in guinea-pigs treated with doses of methotrexate which induced necrotizing enterocolitis (Fox et al. 1988). In a rat feeding study (Grimble et al. 1989) the group of animals fed on a proteinhydrolysate-based diet which contained glutamine showed marked caecal and colonic hypertrophy and hyperplasia, similar in magnitude to that seen during dietary fibre supplementation (Koruda et al. 1986; Rolandelli et al. 1986). It is not clear whether the tropic effect was due to the glutamine content or to malabsorption of the hydrolysate and its fermentation in the large bowel.

\section{Feeding studies in man}

Normal gut function. In two studies where the amino acid content of all diets was carefully controlled there appeared to be no difference in overall absorption or metabolic utilization of protein, protein hydrolysates, or the equivalent amino acid mixtures, in subjects with normal small bowel function (Silk et al. 1979; Moriarty et al. 1985). Thus, in normal man there is sufficient absorptive capacity in the small intestine for efficient assimilation of whole protein.

Impaired gut function. For patients with moderately impaired gastrointestinal function there appears to be no nutritional superiority of protein hydrolysates over whole protein (Rees et al. 1988 b). In pancreatectomized patients (Steinhardt et al. 1989) absorption of a lactalbumin hydrolysate was significantly greater $(91 \%)$ than that of lactalbumin $(61 \%)$. What is most remarkable about this study is that over half the protein was assimilated in the absence of pancreatic enzymes, suggesting that the activity of brush-border endopeptidases against peptic digests of whole protein is quantitatively significant (Song et al. 1986). In patients with $60-150 \mathrm{~cm}$ of the jejunum remaining, two diets containing protein or partially hydrolysed protein were equally well absorbed (McIntyre et al. 1986). When absorptive area was more severely reduced $(50-80 \mathrm{~cm}$ jejunum) no difference was observed in $\mathrm{N}$ balance, $\mathrm{N}$ absorption or $\left[{ }^{13} \mathrm{C}\right]$ leucine kinetics when patients received a wheyprotein-hydrolysate-based or equivalent amino acid-based enteral diet (Rees et al. 1988a). The whey protein hydrolysates used in both studies contained mainly tetra- and pentapeptides and it is possible that their uptake was limited by brush-border hydrolysis.

\section{CONCLUSIONS AND PERSPECTIVES}

It now seems that a significant proportion of dietary $\mathrm{N}$ is absorbed in the form of di- and tripeptides. The peptide and free amino acid transport systems of the small intestine may differ in their handling of the wide variety of dietary proteins, especially in relation to the non-essential amino acids. Thus, where a free amino acid is poorly transported by an easily saturable system its uptake may be faster via the peptide transport system if it is presented in peptide form. A second function of the peptide transport system may be to relieve competition for transport between free amino acids which share the same carrier. This may be especially true in cases where poor protein quality and malabsorption coexist with a high requirement for amino acid residues (e.g. rapid growth in infants).

Despite the differences in absorption of partial hydrolysates of protein or their equivalent amino acid mixtures observed in human intestinal perfusion experiments, there have been relatively few controlled studies of the nutritional efficacy of proteins, hydrolysates or free amino acids in man. At present, only one study has shown that predigestion of protein increases $\mathrm{N}$ absorption in pancreatectomized patients. Where absorptive area is severely reduced (e.g. inadequate short bowel syndrome) there appears to be no advantage of 
medium-chain protein hydrolysates over whole protein or free amino acids. However, recent perfusion studies suggest that brush-border hydrolysis of the peptides of mediumchain hydrolysates may be rate limiting to uptake. It is, thus, possible that hydrolysates containing mainly di- and tripeptides may provide an absorptive benefit to patients with severely reduced intestinal absorptive area.

\section{APPLICATION OF PEPTIDES TO INTRAVENOUS NUTRITION \\ EVIDENCE FOR ENDOGENOUS HYDROLYSIS OF CIRCULATING PEPTIDES}

Several lines of research suggest that the capacity of the human body to hydrolyse circulating peptides is quite large. Significant quantities of peptides may cross the intestinal barrier intact. The kidney appears to be a major site of digestion of circulating peptides and recapture of their constituent amino acids. A number of recent infusion studies with synthetic dipeptides have shown that they are rapidly hydrolysed and metabolized. Finally, peptides were widely used in intravenous nutrition for many years, in the form of partially hydrolysed protein. Although the use of hydrolysates has now been discontinued in favour of solutions of free amino acids, early studies suggested that their constituent peptides were fairly well utilized.

\section{TRANSLOCATION OF PEPTIDES ACROSS THE GASTROINTESTINAL BARRIER}

Two comprehensive reviews have challenged the view that only free amino acids enter the portal circulation after a protein meal (Matthews, $1975 b$; Gardner, 1984). It was noted that significant quantities of hydroxyproline-containing peptides were excreted in urine following a meal of partially hydrolysed gelatin (Prockop et al. 1962; Hueckel \& Rogers, 1970). Since this represented an increase in excretion over basal levels, some of these peptides must have escaped degradation by the enterocyte and entered the portal circulation. Proline-containing peptides are often thought to be a special case because of the resistance of the prolyl bond to hydrolysis (Faull et al. 1976; Walter et al. 1980; Charpentier et al. 1984), but peptidaemia in portal blood has also been noted after casein feeding in dogs (Christensen, 1949), or after perfusion of the small intestine of guinea-pigs with solutions of partially hydrolysed casein (Gardner et al. 1983). In the latter study, a surprisingly wide variety of amino acids were found in peptide-bound form in the blood. According to the authors, this accounted for as much as $15 \%$ of net amino acid release into the portal circulation. These findings suggest that pathways exist for efficient hydrolysis of translocated peptides because, if $15 \%$ of dietary $\mathrm{N}$ enters the circulation in peptide form (Gardner et al. 1983), only a small percentage leaves as such, about $4 \%$ of total $\mathrm{N}$ excretion in man (Lidstrom \& Wretlind, 1952; Grimble et al. 1989).

\section{THE ROLE OF THE KIDNEY IN DISPOSAL OF CIRCULATING PEPTIDES}

The mechanism by which the kidney salvages circulating peptide-bound amino acids is, in some respects, similar to assimilation of peptides by the small intestine. The same membrane-bound peptidases with distinctive structure are found in both organs (Kenny \& Maroux, 1982) and brush-border membrane vesicle preparations from both tissues are 
capable of concentrative uptake of intact dipeptides, driven by a proton gradient (Ganapathy \& Leibach, 1983, 1985; Ganapathy et al. 1984, 1985). Uptake kinetics of amino acids, peptides and maltose in the perfused renal tubule or whole kidney also appear to be remarkably similar to that in the perfused small intestine (Silbernagl, 1977; Silbernagl \& Vokl, 1977; Lowry et al. 1985). Peptides may also be assimilated by luminal endocytosis and intralysosomal degradation to amino acids and peptides (Galaske et al. 1979; Maack et al. 1979; Carone \& Peterson, 1980; Rabkin \& Kitaji, 1983). It is not entirely clear how the structure of a peptide determines whether it is reabsorbed by this mechanism or by brush-border hydrolysis and uptake of small peptides and free amino acids. Certain peptide hormones which are modified by cyclization, extensive disulphide bridging, or $\mathrm{N}$ - and $\mathrm{C}$ terminal blocking (e.g. oxytocin and luteinizing hormone releasing hormone), making them resistant to exopeptidase hydrolysis, do not appear to be hydrolysed at the brush border but may be absorbed by pinocytosis (Peterson et al. 1977; Stetler-Stevenson et al. 1981 ; Rabkin \& Kitaji, 1983).

One particular peptide family, the casomorphins, provide an insight into disposal of circulating peptides. Casomorphins (residues (60-70) are contained within the "bitterpeptide' (residues 53-79) described by Clegg et al. (1974), which may be released from casein during production of partial enzymic hydrolysates of casein for clinical use. All sequences from 60-62 up to 60-70 have been shown to possess opioid activity (see Schlimme et al. 1989). The presence of four proline residues within the sequence (Tyr-ProPhe-Pro-Gly-Pro-Ile-Pro-Asn-Ser-Leu) confers resistance to digestion by pancreatic enzymes (Gardner, 1985; Petrilli et al. 1987) and casomorphins may be translocated across the intestinal wall after milk ingestion (Gardner, 1984). A careful study of the uptake of Tyr-Pro- $\left[{ }^{3} \mathrm{H}\right]$ Phe-Pro-Gly by renal tubule brush-border membrane vesicles has suggested the mode of disposal of circulating casomorphins (Miyamoto et al. 1987). There was no intact uptake of this pentapeptide, but hydrolysis by brush-border dipeptidyl peptidase IV (EC 3.4.14.5) (at the -Pro-Phe- and -Pro-Gly- bonds) released glycine and di- and tripeptide fragments which were absorbed.

\section{INFUSION STUDIES WITH SYNTHETIC DIPEPTIDES}

The fate of injected glycine homopeptides, which are relatively poorly hydrolysed, is markedly affected by their chain length (Adibi \& Krzysik, 1977; Krzysik \& Adibi, 1979; Adibi \& Morse, 1982). Although the liver was a significant site of diglycine utilization, kidney uptake and hydrolysis became the predominant pathways of disposal of tri- and tetraglycine. This probably reflects the fact that peptidases of the kidney tubule have high affinity for and activity towards tri- and tetrapeptides which remain in the circulation for extended periods. Recent comparative studies of two dipeptides which are more or less resistant to hydrolysis (glycylglycine and glycylleucine respectively) have highlighted the role of skeletal muscle and the liver in their disposal (Lochs et al. 1986, 1988). There was no evidence of intact uptake by the liver, and the results were consistent with surface hydrolysis by liver cell membrane peptidases. Leucine and glycine uptake by skeletal muscle was higher during infusion of glycylleucine than during infusion with glycine and leucine. The more resistant peptide, glycylglycine, was predominantly metabolized by the kidney, and more slowly cleared from the circulation. Hind-limb balance studies in post-operative anaesthetized dogs have also shown that the amino acids of infused alanylglutamine are extracted by skeletal muscle almost as well as from mixtures of alanine and glutamine (Roth et al. 1988). Attempts have been made to replace amino acids with di- and tripeptides in long-term animal total parenteral nutrition (TPN) models. In particular, a mixture of Nterminal glycine dipeptides was shown to be as effective as the equivalent amino acid 
Table 2. Problems associated with intravenous protein hydrolysates

\begin{tabular}{|c|c|c|c|}
\hline Problem & Cause & Cure & References \\
\hline $\begin{array}{l}\text { Poor amino acid } \\
\text { pattern }\end{array}$ & $\begin{array}{l}\text { A consequence of } \\
\text { selective loss of amino } \\
\text { acids during processing }\end{array}$ & $\begin{array}{l}\text { Addition of free amino } \\
\text { acids } \\
\text { Different protein or } \\
\text { hydrolysis method }\end{array}$ & $\begin{array}{l}\text { Long et al. (1974), Patel } \\
\text { et al. (1973) }\end{array}$ \\
\hline $\begin{array}{l}\text { Adverse effects } \\
\text { (sweating, headaches, } \\
\text { nausea) }\end{array}$ & $\begin{array}{l}\text { A consequence of high } \\
\text { glutamic acid content } \\
\text { and too rapid infusion } \\
\text { rate }\end{array}$ & Appropriate infusion rate & $\begin{array}{l}\text { Madden et al. (1944), } \\
\text { Heller et al. (1967), } \\
\text { Stegink \& Baker (1971) }\end{array}$ \\
\hline \multirow[t]{2}{*}{ Peptiduria } & $\begin{array}{l}\text { A consequence of too } \\
\text { rapid infusion } \\
\text { A consequence of } \\
\text { Maillard product } \\
\text { formation }\end{array}$ & $\begin{array}{l}\text { Appropriate infusion rate } \\
\text { Avoid heating in presence } \\
\text { of carbohydrates during } \\
\text { manufacture }\end{array}$ & $\begin{array}{l}\text { Silber \& Porter (1949), } \\
\text { Christensen et al. (1955) } \\
\text { Christensen et al. (1955) }\end{array}$ \\
\hline & $\begin{array}{l}\text { Pyrollidone carboxylic } \\
\text { acid during manufacture } \\
\text { of hydrolysate }\end{array}$ & Not known & $\begin{array}{l}\text { Aqvist \& Wretlind (1957), } \\
\text { Heller et al. (1967) }\end{array}$ \\
\hline
\end{tabular}

mixture in maintaining baboons (Papio anubis) in positive $\mathbf{N}$ balance (Steinhardt et al. 1984). Similar results have been obtained in rats infused with alanyltyrosine (Daabees \& Stegink, 1979), glycyltyrosine (Neuhauser 1985), and alanylglutamine (Albers et al. 1984).

\section{LARGE-SCALE USE OF INTRAVENOUS PROTEIN HYDROLYSATES}

Successful intravenous (IV) nutrition was first introduced, over 50 years ago, by Robert Elman who infused mixtures of electrolytes, glucose and amino acids (as partially hydrolysed protein) into patients in sufficient quantities to reverse the oedema and weightloss of long-term malnutrition (Elman, 1947). Commercial production and large-scale clinical use of IV protein hydrolysates continued until the early 1980 s in Europe and the USA, but they have now been replaced by solutions of L-amino acids.

Historical reviews have suggested that the change was due to the inferiority of peptidecontaining hydrolysates to solutions of free amino acids in a number of respects (Table 2; Levenson \& Fisher, 1974; Levenson et al. 1984; Winters et al. 1984). There were several interesting features about large-scale use of IV protein hydrolysates. First, they were a source of IV L-amino acids, at a time when synthetic methods for producing non-racemic mixtures of amino acids were unavailable. They contained considerable quantities of peptides, but this was not considered to be of benefit-rather the reverse. With regard to current interest in IV synthetic dipeptides, the large body of literature on IV protein hydrolysates is extremely relevant. Comparative studies of IV hydrolysates and free amino acid solutions provide an estimate of the capacity of the body to clear infused peptides from the circulation. Finally, the switch to free amino acids was probably driven by marketing and research pressures as much as by reservations about the efficacy of protein hydrolysates. It should be noted that none of the perceived problems with hydrolysates proved to be insurmountable (Table 2).

\section{Comparison with free amino acids}

Of three prospective, controlled clinical trials which have compared IV hydrolysates with IV amino acids or oral protein only one has shown hydrolysates to be as effective in 
Table 3. Selective losses of specific amino acids in three casein hydrolysates

\begin{tabular}{lccc}
\hline \hline & \multicolumn{3}{c}{ Recovery (\%) compared to casein } \\
\cline { 2 - 4 } Amino acid & Aminosol* & Amigen $\dagger$ & $\begin{array}{c}\text { Short-chain preparation } \\
\text { (Table 1, hydrolysate 4) }\end{array}$ \\
\hline Essential & & & \\
Phenylalanine & 109.4 & 61.8 & 95.1 \\
Threonine & 82.5 & 102.1 & 101.8 \\
Non-essential & 21.4 & 14.1 & 91.9 \\
Tyrosine & & & \\
\hline \hline
\end{tabular}

* Adapted from Tweedle (1975).

$\dagger$ Adapted from Patel et al. (1973).

$\ddagger$ Adapted from Chataud et al. (1988).

maintaining patients in $\mathrm{N}$ equilibrium (Tweedle et al. 1973). This was partly due to the poor amino acid pattern of two preparations which contained limiting amounts of cysteine, valine or phenylalanine (Patel et al. 1973; Long et al. 1974). As will be discussed later, an additional problem of the processes used in manufacturing these hydrolysates is the selective loss of some amino acids (Table 3 ).

\section{Peptiduria}

In a number of early studies it was observed that at very high infusion rates a significant proportion of the peptide fraction of the hydrolysate was excreted in the urine (Silber \& Porter, 1949; Christensen, 1950; Christensen et al. 1955). Post-operative stress in parenterally-fed patients also increased excretion of the peptide moiety from 30 to $70 \%$ (Lidstrom \& Wretlind, 1952; Vinnars et al. 1969, 1974), and it was concluded that part of the peptide moiety was intrinsically resistant to renal hydrolysis and reabsorption. The identity of the resistant peptide species remains unclear, but could possible have been prolyl peptides (Hueckel \& Rogers, 1970; Walter et al. 1980) or peptides modified by condensation with sugars during heat sterilization (Christensen et al. 1955). Certainly, the kidney has a large capacity for recapture of small peptides and the peptidases of the renal tubule brush border are both abundant and of wide specificity (Sterchi \& Woodley, 1980; Walter $e t$ al. 1980; Kenny \& Maroux, 1982; Tobey et al. 1985). This has been shown in one study where urinary excretion of glycyl dipeptides was insignificant when they provided the only IV $\mathbf{N}$ source for baboons (Steinhardt et al. 1984).

It is more likely that a large part of the 'peptiduria' observed in earlier studies was artifactual for the following reason. Pyrrolidone carboxylic acid (PCA) is formed from glutamine by intramolecular rearrangement and will only react with ninhydrin after acid treatment has opened the ring structure. Since the classical method for assessing peptiduria has been to measure $\alpha-\mathrm{NH}_{2}-\mathrm{N}$ before and after acid hydrolysis, the presence of significant quantities of excreted PCA will lead to an overestimation of 'peptiduria'. Approximately two-thirds of the glutamate and glutamine residues of casein were converted to PCA during production of one IV hydrolysate (Åqvist \& Wretlind, 1957), and since it is excreted unchanged, during IV infusion it would have made a major contribution to 'peptiduria'. Interestingly, this preparation had acceptably low toxicity (lethal dose about $450 \mathrm{~g}$ given as a single injection; Goldberg \& Wretlind, 1947) and this would cast some doubt on the alleged toxicity of PCA (e.g. Heller et al. 1967; Stehle et al. 1984). What is clear is that conversion of glutamine to PCA, in IV preparations, will prevent utilization of this amino acid. 
Table 4. 'Problem' amino acids

\begin{tabular}{ll}
\hline \hline Amino acid & Problem \\
\hline Glutamine & Unstable in aqueous solution \\
Tyrosine & Relatively insoluble $(0.4 \mathrm{~g} / 1)$ \\
Cysteine & Relatively insoluble $(0 \cdot 1 \mathrm{~g} / 1)$ \\
Tryptophan & Relatively unstable in $\mathrm{O}_{2}$-permeable TPN bags \\
Relatively unstable in $\mathrm{O}_{2}$-permeable TPN bags \\
\hline \hline
\end{tabular}

TPN, total parenteral nutrition.

Clinical and experimental use of IV protein hydrolysates, therefore, suggests that the peptide moiety was substantially utilized, about $30 \%$ for one preparation (Lidstrom \& Wretlind, 1952). Unfortunately, the chain length of these peptides is not known, other than that they were 'dialysable'.

\section{THE RATIONALE FOR INTRAVENOUS PEPTIDES}

\section{Synthetic peptides}

Synthetic peptides are being investigated for IV use for two reasons. Some amino acids (e.g. tyrosine, cystine) are sparingly soluble in free form but in heteropeptide form are very soluble. This is mainly a problem of IV solution formulation and will be discussed later (Table 4). A second reason is that there is some evidence that glutamine may be of importance to the septic or traumatized patients and may be provided in the form of alanylglutamine.

Evidence for a role for glutamine in septic or traumatized patients. During the catabolic response to injury or sepsis the relative rates of protein synthesis and breakdown are altered such that there is net protein breakdown (Rennie, 1985), in part mediated by a loss of functioning ribosomes--the machinery of protein synthesis (Wernerman et al. 1987). The proportion of net amino acid efflux from skeletal muscle which comprises glutamine markedly increases during fasting (Magnusson et al. 1987a; Wood et al. 1988), or in malnourished and traumatized patients (Askanazi et al. 1980; Fürst et al. 1987). As a consequence, muscle intracellular glutamine concentrations have been shown to be reduced. Rennie and co-workers have suggested that this is related to the characteristics of a glutamine transport system unique to skeletal muscle (Rennie et al. 1986). According to this model, net glutamine efflux from skeletal muscle accompanies post-traumatic changes in this $\mathrm{Na}^{+}$-linked glutamine transport system. Taken alone, this would be a metabolic curiosity were it not for the strong correlation between rates of muscle protein synthesis and intracellular glutamine levels (Jepson et al. 1988). Post-traumatic efflux of glutamine may provide a specific fuel for the gastrointestinal tract (Windemueller, 1982; Souba et al. 1985 ) and cells of the immune system (Newsholme et al. 1985, 1987) in order to maintain the barrier function of the former and the ability of the latter to mount an appropriate response. It has, therefore, been proposed that IV amino acid solutions for septic or traumatized patients should be supplemented with glutamine (Fürst et al. 1987; Wilmore et al. 1988).

Possible sources of glutamine for intravenous use. The free amino acid is cheap but relatively unstable in solution, being converted to PCA during heat sterilization. In contrast, $\mathrm{N}$-acetylglutamine is stable (but also cheap) and after injection is deacetylated at the renal tubule brush border, liberating glutamine which may be reabsorbed. 
Unfortunately, deacetylase activity is limited such that in normal and post-operative subjects the upper limit of utilization is only 5-6 g glutamine/d (Magnusson et al. 1987 b), excess being excreted as $N$-acetylglutamine. Glutamine may be presented in peptide-bound form. Alanylglutamine has been produced by chemical or enzymic synthesis, and is both stable and soluble (see p. 14). Alternatively, glutamine precursors have been considered for IV use. The ornithine salt of $\alpha$-ketoglutarate, $\alpha$-ketoglutarate and glutamine appear to be equally effective in reducing post-operative $\mathrm{N}$ losses, muscle polysome disaggregation and the loss of muscle intracellular glutamine (Leander et al. 1985; Wernerman et al. 1987; Hammarkvist et al. 1988, 1989).

Metabolic efficacy of alanylglutamine. In the post-operative dog, hind-limb efflux of glutamine may be reversed by infusion of glutamine itself. In one study alanylglutamine was almost as effective as the free amino acids in bringing muscle into balance or positive balance (Roth et al. 1988). In order to test whether this is of clinical as well as physiological significance. Fürst and colleagues have performed a prospective, randomized trial in which TPN mixtures were supplemented with either alanylglutamine + glycyltyrosine or isonitrogenous amounts of alanine + glycine (Stehle et al. 1989). Peptide supplementation significantly reduced post-operative $\mathrm{N}$ losses, and a post-operative reduction in muscle glutamine (about $\mathbf{4 0} \%$ in the control group) was not observed. This information, therefore, provides the first confirmation that IV glutamine peptides may confer metabolic benefit to septic or traumatized patients.

\section{Short-chain protein hydrolysates}

Intravenous protein hydrolysates in the form in which they were manufactured are, essentially, a dead issue. However, there have been a number of advances in the enzymology of large-scale protein hydrolysis (Chataud et al. 1986a, b, 1988). As described before, the absorptive characteristics of a number of short-chain hydrolysates of ovalbumin and casein have been defined (Grimble et al. 1987; Rees et al. 1988c). The kidney and small intestine appear to handle small peptides in a similar fashion (see p. 7) and, therefore, it seemed possible that a short-chain hydrolysate containing mainly di- and tripeptides (rather than tetra- and higher peptides) would be well utilized as an IV N source. In a crossover study, healthy human subjects were infused with a complete TPN mixture (glucose, lipid, $\mathrm{N}$ ) at a rate which met daily energy and $\mathrm{N}$ requirements. One TPN mixture contained a partial hydrolysate of ovalbumin (about $75 \%$ di- and tripeptides, hydrolysate 1, Table 1) and during the second experiment this was replaced with the equivalent amino acid mixture. Excess peptide excretion during the hydrolysate infusion accounted for only $6 \%$ of total $\mathrm{N}$ excretion, and this suggests that a large proportion of the hydrolysate was metabolized (Grimble et al. 1988).

This preparation differs markedly from the previous generation of IV hydrolysates in that only a small proportion of the constituent amino acids exists in the free form, whilst the majority are in the form of di- to pentapeptides. There may be a number of advantages with these short-chain hydrolysates. Their reduced osmolarity (compared to the equivalent free amino acid mixture) may make them a suitable $\mathbf{N}$ source for peripheral administration. Less than $10 \%$ of those amino acids which are themselves relatively insoluble or unstable (tyrosine, cystine, glutamine, tryptophan) were found to exist in free form in a short-chain casein hydrolysate (hydrolysate 3 , Table 1) which comprised $95.5 \%$ di- to tetrapeptides, prepared by a similar method to the ovalbumin hydrolysate (Chataud et al. 1986 b). It is possible that these amino acid residues may prove to be soluble and stable, long-term, in peptide form in this type of preparation. Short-chain hydrolysates for IV use may also be more economical than free amino acids or synthetic peptides, as suggested by Tweedle (1975). 
There are, however, two potential problems with protein hydrolysates. It was noted that dogs or human subjects infused with protein hydrolysates or free amino acid mixtures at very high rates developed nausea and other adverse effects (Madden et al. 1944; Vinnars et al. 1970). This was related to the glutamate content of these preparations, and the problem was not observed in the clinical setting if an appropriately slow hydrolysate infusion rate was used to provide $\mathrm{N}$ requirements over $24 \mathrm{~h}$ (Filer \& Stegink, 1973).

A potentially more serious complication with IV protein hydrolysates has been that enzymic hydrolysis of protein may unmask epitopes against which a patient may have developed intolerance, through exposure to the protein in the normal diet (see Ferguson \& Watret, 1988). Although antigenicity testing of IV hydrolysates is well described (US Pharmacopeia, 1980), the potential seriousness of anaphylactic reactions cannot be overemphasized and has, one suspects, been a major reason for the change to non-allergic amino acids for IV infusion. However, we have been unable to find any reports of anaphylactic reactions to IV protein hydrolysates in the literature, and only one study cites evidence of an allergic type of response, in one subject (Heller et al. 1967).

The cut-off point for antigenicity appears to be eight to ten amino acid residues, and for one casein hydrolysate the number of casein determinants was markedly reduced by extensive enzymic hydrolysis to small peptides (Knights, 1984). We have observed that of three short-chain hydrolysates of ovalbumin, lactalbumin and casein prepared by the same method, only one (casein) required further hydrolysis to remove epitopes recognized in the US Pharmacopeia (1980) test. The reason for this difference is not clear but may be related to particular post-transcriptional modifications to casein (e.g. phosphorylation, glycosylation). Certainly, analysis by gas-liquid chromatography-mass spectrometry (GLC-MS) suggested that the initial hydrolysate contained small quantities of glycopeptides, which could be removed by resin treatment (Ford et al. 1986).

\section{CONCLUSIONS AND PERSPECTIVES}

The evidence summarized suggests that the human body has a large capacity to metabolize small peptides in the circulation. Two recent studies have, therefore, shown that it is possible to supply daily $\mathrm{N}$ requirements, intravenously, as small peptides (Steinhardt $e t$ al. 1984; Grimble et al. 1988).

Synthetic dipeptides provide a way to avoid the problems of stability and solubility which exist with solutions of free amino acids. At the same time, a recent clinical trial of alanylglutamine suggests that it is a safe and effective vehicle for IV administration of glutamine to post-operative patients. Short-chain protein hydrolysates may also have a number of advantages in terms of peripheral administration, amino acid stability and cost.

IV amino acid solutions have replaced peptide-containing preparations, on fairly species grounds. Although these solutions have proved to be an effective means of providing IV N, it is ironic that the renaissance in IV peptide research has come about because of the deficiencies of some of the free amino acids themselves.

\section{PRODUCTION OF SYNTHETIC DIPEPTIDES OR PROTEIN HYDROLYSATES FOR CLINICAL USE}

\section{SYNTHETIC DIPEPTIDES}

Two methods have been used to synthesize stable and soluble di- and tripeptides, which contain unstable or insoluble amino acids. Conventional methods of synthesis have been applied to production of peptides containing tyrosine, glutamine and cysteine (Stehle et al. 
Table 5. Technical considerations for hydrolysates for use in clinical nutrition

Cost $v$. enzymes used

Starter protein

Degree of hydrolysis $v$. taste properties

Solubility $v$. degree of hydrolysis

Stability of individual peptide species

Emulsificant properties of hydrolysate $v$. stability of liquid diet

Final treatment $v$. effects on amino acid composition

1982; Stehle, 1988). Proteolytic enzymes have also been used to synthesize a number of dipeptides. The largest contribution to the free energy change during hydrolysis of a peptide bond comes from the ionization of the liberated amino and carboxyl groups. Thus, if these groups on two substrate amino acids are 'blocked', then the reverse reaction, peptide-bond synthesis, may be catalysed by the enzyme under mild conditions (Fruton, 1982; Konopinska \& Muzalewski, 1983; Jakubke et al. 1985). The major advantages of the enzyme method are stereospecificity of the reaction, lack of racemization and better economy in large-scale production (Fruton, 1982).

\section{PROTEIN HYDROLYSATES}

At first sight, production of protein hydrolysates for nutritional use would seem to be fairly straightforward but there are a number of conflicting requirements which have to be met during manufacture (Table 5).

\section{Amino acid adequacy}

Trypsin and chymotrypsin have been widely used in production of milk protein hydrolysates (Kilara, 1985; Adler-Nissen, 1986a) but their bond specificity (Desnuelle 1986) and the presence of sequences of the type -Arg-Tyr-, -Lys-Tyr-, -Phe-Tyr-, or -PhePhe- in casein (Lyster, 1972) will result in release of free tyrosine and phenylalanine. Tyrosine is sparingly soluble and, like phenylalanine, may be adsorbed onto activated charcoal during any decolorization steps used in manufacture. It is, therefore, not surprising that there were selective losses of these two amino acids in IV casein hydrolysates produced by pancreatic enzyme digestion (Table 3). The use of other proteolytic enzymes is discussed by Adler-Nissen (1986a).

\section{Taste properties}

A second feature of endopeptidase digestion is the release of peptides with strong taste properties (e.g. 'cheesy', 'bitter' or 'interesting'). Although casein is a nutritionally adequate protein, 'bitter' flavours in a hydrolysate will prevent its administration to patients by anything other than the nasoenteral route. The phenomenon of peptide bitterness has been shown to occur if the average hydrophobicity of peptide exceeds 5.86 MJ (1400 cal)/mol (Ney 1978, 1979). This scheme has been further refined (Adler-Nissen, 1986b). Maximum bitterness also occurs if the hydrophobic amino acid residue is adjacent to, but not at the $\mathrm{N}$ or $\mathrm{C}$ terminal of small peptides (Matoba \& Hata, 1972). The value of this approach has been demonstrated for partial enzymic hydrolysates of casein, which contain the 'bitter' sequence of residues 53-79 (Clegg et al. 1974), encompassing the $\beta$ casomorphin sequences (Schlimme et al. 1989). Exopeptidase digestion of this peptide reduced the $Q$ value (average hydrophobicity) from $1400 \mathrm{cal} / \mathrm{mol}$ to $<1100 \mathrm{cal} / \mathrm{mol}$, by releasing a number of hydrophobic amino acids; bitterness was also reduced 100 -fold 
(Umetsu et al. 1983; Fullbrook et al. 1987) and the mechanism of the latter change was that hydrophobic residues were either removed from the sequence or were exposed at the C- or N-terminal (Adler-Nissen, 1986b).

Non-bitter hydrolysates may prove to be a useful method of protein-supplementing foodstuffs, in situations where whole protein would be unstable because of the acidity of the food.

\section{Peptide chain length}

As described previously, the absorptive properties of a protein hydrolysate may vary with peptide chain length. One group have investigated methods for producing hydrolysates with minimal free amino acid content, but which contain mainly di-, tri- and tetrapeptides (about 95 total amino acids) for use as an enteral and parenteral $\mathrm{N}$ source (Chataud et al. $1986 a, b, 1988$; Grimble et al. 1987, 1988). Several peptidases were added in a carefully controlled sequence, such that each operated at its $\mathrm{pH}$ optimum and expressed most activity at primary cleavage sites with little release of free amino acids. The peptide chainlength profiles of hydrolysates, prepared by this method and by the conventional technique of adding all enzymes together, are compared in Table 1. It can be seen that the product of the sequential enzyme method has a narrower chain-length profile, and low free amino acid content. Since the majority of the 'problem' amino acids are in peptide form, losses during processing have been shown to be minimal (Chataud et al. 1986a, $h, 1988$ and Table 3).

\section{Glutamine content}

The effect of sequence on the stability of glutamine residues in a number of synthetic peptides for IV use has been carefully investigated (Stehle, 1988). Unfortunately, this has not been the case with the proteins and hydrolysates currently used in enteral diets. In an interesting review, Robinson \& Rudd (1974) determined the effect of sequence of sixty-four pentapeptides of the type Gly-X-Asn-Y-Gly or Gly-X-Gln-X-Gly on the rate of deamidation of the asparagine or glutamine residues. Curiously, asparaginyl residues were less stable than glutaminyl residues, the reverse of the situation for the free amino acids. The presence of an adjacent hydrophobic amino acid in the sequence stabilized the amide group. Other factors affecting stability are discussed in more detail elsewhere (Robinson \& Rudd, 1974).

Liquid enteral diets have several clinical and convenience advantages over powdered diets which must be reconstituted before use. This is a novel situation because there may be extensive deamidation of glutamine and asparagine residues in the protein or peptide moiety of presterilized liquid enteral diets during their long shelf-life. As has been described previously, a high glutamine intake may be of particular value to septic or traumatized patients. Could there be a need to investigate the stability of glutamine residues in liquid enteral diets, as has been done for synthetic peptide-based TPN formulas?

\section{Analysis}

Because only a small number of synthetic peptides have been used for IV nutrition, this has simplified analysis and a number of investigators have reported accurate clearance rates during infusion studies (Stehle et al. 1984; Steinhardt et al. 1984; Lochs et al. 1988; Stehle 1988).

Complete analysis of protein hydrolysates in terms of amino acid composition, peptide chain-length distribution and constituent peptide sequences is a more complex problem. Although the average peptide chain length of a hydrolysate may be measured from the ratio of detectable $\alpha-\mathrm{NH}_{2}$ groups before and after acid hydrolysis, correction is required for the 
free amino acid content and presence of pyrGlu (see p. 96). Size exclusion chromatography (SEC) of hydrolysates has been claimed to produce a satisfactory distribution profile of short-chain hydrolysates (Knights, 1984). This technique is valid if the polymers under study have a close chemical equivalence and minimal interaction with the packing, as in the case of maltodextrins (Grimble \& Adam, 1989). In our experience, we have found it almost impossible to suppress ionic, charge-transfer and hydrophobic interactions which occur between peptides and the SEC packing, and it is highly unlikely that this method can be applied to the heterogenous mixture of peptides found in most hydrolysates. $\mathrm{Cu}$ (II)chelation chromatography may be a more valid technique since elution position is strongly dependent on the number of peptide bonds (Rothenbühler et al. 1979). Capillary GLC-MS has been used to sequence proteins by analysing the dipeptides released during dipeptidyl peptidase IV digestion (Dizdaroglu \& Simic, 1980; Krutzsch, 1983). Since a nutritional protein hydrolysate may be considered in the same way, we (Ford et al. 1986) and others (Corbett et al. 1987) have used the same technique to analyse short-chain protein hydrolysates and synthetic dipeptides.

\section{CONCLUSIONS AND PERSPECTIVES}

Large-scale chemical synthesis of specific di- and tripeptides is a very satisfactory solution to a number of formulation problems in parenteral nutrition. Purification may be relatively straightforward, and purity and stability are easily assessed because of the simplicity of the compounds involved. Whether they can be produced economically without making a significant impact on the price of parenteral amino acid preparations is not yet clear.

There have also been several advances in the biotechnology of large-scale protein hydrolysis. It would be overstating the case to say that hydrolysates can be completely 'engineered', but two formidable problems (chain length and bad taste) appear to have been overcome. Thus, it is quite feasible to produce protein hydrolysates with superior absorptive properties to their equivalent free amino acid mixtures, but at lower cost.

This line of reasoning can lead to a number of alarming conclusions. First, since peptide uptake in the small intestine is a significant mechanism for $\mathrm{N}$ assimilation, is it logical to use free amino acids as the only $\mathrm{N}$ source for patients with severely impaired gut function? Second, is there a need for free amino acids in parenteral nutrition at all? Evidence reviewed here suggests that amino acid requirements may be met by infusion of mixtures of synthetic dipeptides or short-chain peptides. It is, thus, possible that peptides will come to play a significant role in clinical nutrition after all.

\section{REFERENCES}

Adibi, S. A. (1971). Intestinal transport of dipeptides in man: relative importance of hydrolysis and intact absorption. Journal of Clinical Investigation 50, 2266-2275.

Adibi, S. A. \& Krzysik, B. A. (1977). Effect of nephrectomy and enterectomy on plasma clearance of intravenously administered dipeptides in the rat. Clinical Science \& Molecular Medicine 52, 205-213.

Adibi, S. A. \& Morse, E. L. (1977). The number of glycine residues which limits intact absorption of glycine oligopeptides in human jejunum. Journal of Clinical Investigation 60, 1008-1016.

Adibi, S. A. \& Morse, E. L. (1982). Enrichment of glycine pool in plasma and tissues by glycine, di-, tri-, and tetraglycine. American Journal of Physiology 243, E413-417.

Adler-Nissen, J. (1986a). Enzymic Hydrolysis of Food Proteins. London: Elsevier Applied Science Publishers.

Adler-Nissen, J. (1986 b). Relationship of structure to taste of peptides and peptide mixtures. In Protein Tailoring For Food and Medical U.ses, pp. 97-122 [R. E. Feeney and J. R. Whitaker, editors]. New York: Marcel Dekker Inc.

Albers, S., Amberger, I., Mangold, J., Pfaender, P. \& Fürst, P. (1984). Das synthetische Dipeptid L-Alanyl-Lglutamin als Glutaminequelle in der parenteralen Ernährung. II. Der Einsatz des Peptides in der experimenteller Kalabolie (The synthetic dipeptide L-alanyl-L-glutamine as a glutamine source in parenteral nutrition. IJ. Utilization of dipeptides in experimental catabolism). Infusionstherapie 11, 57-58. 
Åqvist, S. \& Wretlind, A. (1957). Pyrolidone carboxylic acid in enzymatic casein hydrolysates. Acta Physiologica Scandinavica 39, 147-157.

Askanazi, J., Carpentier, Y. A., Michelsen, C. B., Elwyn, D. M., Fürst, P., Kantrowitz, L. R., Gump, F. E. \& Kinney, J. M. (1980). Muscle and plasma amino acids following injury. Annals of Surgery 192, 78-85.

Botbol, V. \& Scornik, O. A. (1983). Peptide intermediates in the degradation of cellular proteins. Journal of Biological Chemistry 258, 1942-1949.

Boyd, C. A. R. \& Ward, M. R. (1982). A micro-electrode study of oligopeptide absorption by the small intestinal epithelium of Necturus maculosus. Journal of Physiology 324, $411-428$.

Burston, D. \& Matthews, D. M. (1984). The effects of sodium replacement on peptide uptake by the small intestine. In Nutrition for Special Needs in Infancy: Protein Hydrolysates, pp. 23-35. [F. Lifshitz, editor]. New York: Marcel Dekker Inc.

Burston, D., Taylor, E. \& Matthews, D. M. (1979). Intestinal handling of two tetrapeptides by rodent small intestine. Biochimica et Biophysica Acta 553, 175-178.

Burston, D., Wapnir, R. A., Taylor, E. \& Matthews, D. M. (1982). Uptake of L-valyl-L-valine and glycyl-sarcosine by hamster jejunum in vitro. Clinical Science 62, 617-626.

Carone, F. A. \& Peterson, D. R. (1980). Hydrolysis and transport of small peptides by the proximal tubule. American Journal of Physiology 238, F151-158.

Chacko, A. \& Cummings, J. H. (1988). Nitrogen losses from the human small bowel: obligatory losses and the effect of physical form of food. Gut 29, 809-815.

Charpentier, C., Johnstone, R. A. W., Lemonnier, A., Myara, I., Rose, M. E. \& Tuli, D. (1984). Analysis of dipetides in urine by gas chromatography/mass spectrometry: implications for collagen breakdown in iminodipeptiduria following the study of the dipeptides by electron impact and chemical ionization. Clinica Chimica Acta 138, 299-308.

Chataud, J., Desreumaux, S. \& Cartwright, T. (1986a). Procédé de fabrication d'un hydrolysat enzymatique de protéines riche en di- et tri-peptides, utilisable notamment en nutrition artificielle et en diététique (Process for the manufacture of an enzymic protein hydrolysate rich in dipeptides and tripeptides, which can be used especially in artificial nutrition and dietetics). French Patent 86, 17516.

Chataud, J., Desreumaux, S. \& Cartwright, T. (1986b). Procédé de préparation d'un mélange peptidique, riche en di- et tri-peptides, utilisable notamment en nutrition artificielle et en diététique, mélange ainsi obtenu, et utilisation de ce mélange en nutrition artificielle et en diététique (Process for the preparation of a peptide mixture rich in dipeptides and tripeptides, which can be used especially in artificial nutrition and dietetics, the mixture thus obtained and the use of this mixture in artificial nutrition and dietetics). French Patent 86, 17515.

Chataud, J., Desreumaux, S. \& Cartwright, T. (1988). Industrial scale production of di- and tripeptides. Proceedings of 8th International Biotechnology Symposium, Paris. p. 218, Paris: Société Français de Microbiologie.

Christensen, H. N. (1949). Conjugated amino acids in portal plasma of dogs after protein feeding. Biochemical Journal 44, 333-335.

Christensen, H. N. (1950). Peptide wastage consequent to the infusion of two protein hydrolysates. Journal of Nutrition 42, 189-193.

Christensen, H. N., Wilber, P. B., Coyne, B. A. \& Fisher, J. H. (1955). Effects of simultaneous or prior infusion of sugars on the fate of infused protein hydrolysates. Journal of Clinical Investigation 34, 86-94.

Chung, Y. C., Kim, Y. S., Shadchehr, A., Garrido, A., MacGregor, I. L. \& Sleisinger, M. H. (1979). Protein digestion and absorption in human small intestine. Gastroenterology 76, 1415-1421.

Clegg, K. M., Lim, C. L. \& Manson, W. (1974). The structure of a bitter peptide derived from casein by digestion with papain. Journal of Dairy Research 41, 283-287.

Corbett, M. E., Scrimgeour, C. M. \& Watt, P. W. (1987). Use of tert.-butyldimethylsilyl derivatives for gas chromatographic-mass spectrometric analysis of dipeptides. Journal of Chromatography 419, 263-270.

Curtis, K. J., Kim, Y. S., Perdomo, J. M., Silk, D. B. A. \& Whitehead, J. S. (1978). Protein digestion and absorption in the rat. Journal of Phvsiology 274, 409-419.

Daabees, T. T. \& Stegink, L. D. (1979). L-Alanyl-L-Tyrosine during total parenteral nutrition: infusion of 0.5 and $2.0 \mathrm{mmoles} / \mathrm{kg} /$ day in adult rats. Pediatric Research 13, 894-899.

Desnuelle, P. (1986). Chemistry and enzymology of pancreatic endopeptidases. In Molecular and Cellular Basis of Digestion, pp. 195-211 [P. Desnuelle, H. Sjöström and O. Norén, editors]. Amsterdam: Elsevier.

Dizdaroglu, M. \& Simic, M. G. (1980). Separation of dipeptides by high resolution gas chromatography on a fused silica capillary column after trimethylsilylation. Analytical Biochemistry 108, 269-273.

Elman, R. (1947). Parenteral Alimentation in Surgery. With Special Reference to Proteins and Amino Acids. New York: Paul B. Hoeber Inc.

Fairclough, P. D., Hegarty, J. E., Silk, D. B. A. \& Clark, M. L. (1980). A comparison of the absorption of two protein hydrolysates and their effects on water and electrolyte movements in the human jejunum. Gut 21, 829-834.

Faull, K. F., Schlesinger, P. \& Halpern, B. (1976). The mass spectrometric identification of dipeptides in the urine of a patient suffering from chronic skin ulceration and oedema. Clinica Chimica Acta 70, 313-321.

Ferguson, A. \& Watret, K. C. (1988). Cow' milk intolerance. Nutrition Research Reviews 1, 1-22. 
Filer, L. J. \& Stegink, L. D. (1973). Safety of hydrolysates in parenteral nutrition. New England Journal of Medicine 289, 426-427.

Ford, C., Grimble, G. K., Halliday, D. \& Silk, D. B. A. (1986). Gas chromatography-mass spectrometry analysis of dipeptides in nutritionally significant enzyme hydrolysates of ovalbumin and casein. Biochemical Society Transactions 14, 1291-1293.

Fox, A. D., Kripke, S. A., De Paula, J., Berman, J. F., Settle, R. G. \& Rombeau, J. L. (1988). Effect of glutaminesupplemented enteral diet on methotrexate-induced enterocolitis. Journal of Parenteral \& Enteral Nutrition 12 , 325-331.

Freeman, H. J., Sleisinger, M. H. \& Kim, Y. S. (1983). Human protein digestion and absorption: normal mechanisms and protein energy malnutrition. In Clinics in Gastroenterology, vol. 12 pp. 357-378 [M. H. Sleisinger, editor] London: W. B. Saunders.

Fruton, J. S. (1982). Proteinase-catalysed synthesis of peptide bonds. Advances in Enzymology 53, 239-306.

Fullbrook, P., Pawlett, D. \& Parker, D. (1987). Protein plus. Food Processing 56 (12), 11-13.

Fürst, P., Albers, S. \& Stehle, P. (1987). Stress-induced intracellular glutamine depletion. The potential use of glutamine containing peptides in parenteral nutrition. In: Dipeptides as New Substrates in Nutrition Therapy, pp. 117-136 [S. A. Adibi, W. Fekl and M. Oehmke, editors]. Munich: Karger.

Galaske, R. G., van Ljew, J. B. \& Feld, L. G. (1979). Filtration and reabsorption of endogenous low-molecularweight protein in the rat kidney. Kidney International 16, 394-403.

Ganapathy, V., Burckhardt, G. \& Leibach, F. K. (1984). Characteristics of glycylsarcosine transport in rabbit intestinal brush-border membrane vesicles. Journal of Biological Chemistry 259, 8954-8959.

Ganapathy, V.. Burckhardt, G. \& Leibach. F. H. (1985). Peptide transport in rabbit intestinal brush-border membrane vesicle studied with a potential-sensitive dye. Biochimica et Biophysica Acta 816, 234-240.

Ganapathy, V. \& Leibach, F. K. (1983). Role of pH gradient and membrane potential in dipeptide transport in intestinal and renal brush-border membrane vesicles from the rabbit. Journal of Biological Chemistry 258 , $14189-14192$.

Ganapathy, V. \& Leibach, F. K. (1985). Is intestinal transport energized by a proton gradient? American Journal of Physiology 249, G153-G160.

Ganapathy, V., Mendicino, J. F. \& Leibach, F. H. (1981). Transport of glycyl-L-proline into intestinal and renal brush border vesicles from rabbit. Journal of Biological Chemistry 256, 118-124.

Gardner, M. L. G. (1984). Intestinal assimilation of intact peptides and proteins from the diet - a neglected field. Biological Reviews 59, 289-331.

Gardner, M. L. G. (1985). Production of pharmacologically active peptides from foods in the gut. In Food and the Gut, pp. 121 134 [J. O. Hunter and V. Alun Jones, editors]. London: Balliere Tindall.

Gardner, M. L. G., Lindblad, B. S., Burston, D. \& Matthews, D. M. (1983). Transmucosal passage of intact peptides in the guinea-pig small intestine in vivo: a reappraisal. Clinical Science 64, 433-439.

Gibson, G. R., Cummings, J. H. \& MacFarlane, G. T. (1988a). Use of a three-stage continuous culture system to study the effect of mucin on dissimilatory sulphate reduction and methanogenesis by mixed populations of human gut bacteria. Applied and Environmental Microbiology 54, 2750-2755.

Gibson, G. R., MacFarlane, G. T. \& Cummings, J. H. (1988b). Occurrence of sulphate-reducing bacteria in human faeces and the relationship of dissimilatory sulphate reduction to methanogenesis in the large gut. Journal of Applied Bacteriology 65, 103-111

Goldberg, L. \& Wretlind, K. A. J. (1947). The toxicity of a dialysed casein digest. Acta Physiologica Scandinavica 14. $19-26$.

Gray, G. M. \& Cooper, H. L. (1971). Protein digestion and absorption. Gastroenterology 61, $535-544$.

Grimble, G. K. (1989). Leading article: Fibre, fermentation, flora and flatus. Gut 30, 6-13.

Grimble, G. K. \& Adam, A. M. (1989). HPLC analysis of sugars in clinical research. Chromatography and Analysis 2, 5-8.

Grimble, G. K., Keohane, P. P., Higgins, B. E., Kaminski, M. V. \& Silk, D. B. A. (1986). Effect of peptide chainlength on amino acid and nitrogen absorption from two lactalbumin hydrolysates in the normal human jejunum. Clinical Science 71, 65-69.

Grimble, G., Preedy, V., Garlick, P. \& Silk, D. B. A. (1989). Trophic effects of dietary peptides on the rat intestinal tract. Journal of Parenteral \& Enteral Nutrition 13, Suppl., 6S.

Grimble, G. K., Raimundo, A. H., Rees, R. G., Hunjan, M. K. \& Silk, D. B. A. (1988). Parenteral utilisation of a purified short-chain enzymic hydrolysate of ovalbumin in man. Journal of Parenteral \& Enteral Nutrition 12 , Suppl., 15S.

Grimble, G. K., Rees, R. G., Keohane, P. P., Cartwright, r., Desreumaux, M. \& Silk, D. B. A. (1987). The effect of peptide chain-length on absorption of egg-protein hydrolysates in the normal human jejunum. Gastroenterology 92, 136-142.

Grimble, G. K. \& Silk, D. B. A. (1986). The optimum form of dietary nitrogen in gastrointestinal disease: proteins, peptides or amino acids. Verhandlungen der Deutschen Gesellschaft für Innere Medizin 92, 674-685.

Grimble, G. K. \& Silk, D. B. A. (1989). Milk protein and enteral and parenteral feeding in disease. In Milk Proteins: Nutritional, Functional and Technological Aspects, pp. 270-282 [C. A. Barth and E. Schlimme, edtitors]. Darmstadt: Steinkopff Verlag. 
Guandalini, S. \& Rubino, A. (1982). Development of dipeptide transport in the intestinal mucosa of rabbits. Pediatric Research 16, 99-103.

Hammarkvist, F., Wernerman, J., Ali, R., von der Decken, A. \& Vinnars, E. (1988). Effects of glutamine supplementation to total parenteral nutrition after elective abdominal surgery. Clinical Nutrition 7, Suppl., 36.

Hammarkvist, F., Wernerman, J, \& Vinnars, E. (1989). Alpha-ketoglutarate added to post-operative total parenteral nutrition improves nitrogen balance and reduces the loss of free glutamine in skeletal muscle. Journal of Parenteral \& Enteral Nutrition 13, Suppl., 6S.

Hegarty, J. E., Fairclough, P. D., Moriarty, K. J., Kelly, M. J. \& Clark, M. L. (1982). Effects of concentration on in vivo absorption of a peptide containing protein hydrolysate. Gut. 23, 304-309.

Heller, L., Becher, A., Beck, A. \& Muller, F. (1967). Zur Frage der Verwertung infundierter Aminosäurenlösung (On the utilization of infused amino acid solutions). Klinische Wochenschrift 45, 317-318.

Hueckel, H. J. \& Rogers, Q. R. (1970). Urinary excretion of hydroxyproline-containing peptides in man, rat, hamster, dog and monkey after feeding gelatin. Comparative Biochemistry \& Physiology 32, 7-16.

Itoh, H., Kishi, T. \& Chibata, I. (1973). Comparative effects of casein and amino acid mixture simulating casein on growth and food intake in rats. Journal of Nutrition 103, 1709-1715.

Jakubke, H. D., Kuhl, P. \& Konnecke, A. (1985). Grundprinzipien der proteasekatalysierten Knüpfung der Peptidbundung. (Theory of protease-catalysed peptide bond synthesis.) Angewandte Chemie 97, 79-89.

Jepson, M. M., Bates, P. C., Broadbent, P., Pell, J. M. \& Millward, D. J. (1988). Relationship between glutamine concentration and protein synthesis in rat skeletal muscle. American Journal of Physiology 255, E166-E172.

Kenny, A. J. \& Maroux, S. (1982). Topology of microvillar membrane hydrolases of kidney and intestine. Physiological Reviews 62, 91-128.

Keohane, P. P., Grimble, G. K., Brown, B., Spiller, R. C. \& Silk, D. B. A. (1985). Influence of protein composition and hydrolysis method on intestinal absorption of protein in man. Gut 26, 907-913.

Kilara, A. (1985). Enzyme-modified protein food ingredients. Process Biochemistry 20, 149-157.

Knights, R. J. (1984). Processing and evaluation of the antigenicity of protein hydrolysates. In Nutrition for Special Needs in Infancy: Protein Hydrolysates, pp. 105-115 [F. Lifshitz, editor] New York: Marcel Dekker.

Konopinska, D. \& Muzalewski, F. (1983). Proteolytic enzymes in peptide synthesis. Molecular \& Cellular Biochemistry 51, 165-175.

Koruda, M. J., Rolandelli, R. H., Settle, R. G., Saul, S. H. \& Rombeau, J. L. (1986). The effect of a pectinsupplemented elemental diet on intestinal adaptation to massive small bowel resection. Journal of Parenteral \& Enteral Nutrition 10, 343-350.

Krutzsch, H. C. (1983). Polypeptide sequencing with dipeptidyl peptidases. Methods in Enzymology 91, 511-524.

Krzysik, B. A. \& Adibi, S. A. (1979). Comparison of metabolism of glycine injected intravenously in free and dipeptide forms. Metabolism 28, 12!1-1217.

Leander, U., Fürst, P. Vesterberg, K. \& Vinnars, E. (1985). Nitrogen sparing effect of Ornicetil ${ }^{\star}$ in the immediate postoperative state: clinical biochemistry and nitrogen balance. Clinical Nutrition 4, 43-51.

Levenson, S. M. \& Fisher, H. (1974). Amino acids and protein hydrolysates; calories : nitrogen: disease and injury relationships. In Total Parenteral Nutrition pp. 92-143 [P. L. White, M. E. Nagy and D. C. Fletcher, editors]. Acton, MA: Publishing Sciences Group Inc.

Levenson, S. M., Smith Hopkins, B., Waldron, M., Canham, J. E. \& Seifter, E. (1984). Early history of parenteral nutrition. Federation Proceedings 43, 1391-1406.

Lidstrom, F. \& Wretlind, K. A. J. (1952). The effect of intravenous administration of a dialysed. enzymic casein hydrolysate (Aminosol) on the serum concentration and on the urinary excretion of amino acids. Scandinavian Journal of Clinical \& Laboratory Investigation 4, 167-178.

Lochs, H., Morse, E. L. \& Adibi, S. A. (1986). Mechanism of hepatic assimilation of dipeptides. Transport versus hydrolysis. Journal of Biological Chemistry 261, 14976-14981.

Lochs, H., Williams, P. E., Morse, E. L., Abumrad, N. N. \& Adibi, S. A. (1988). Metabolism of dipeptides and their constituent amino acids by liver, gut, kidney and muscle. American Journal of Physiology 254, E588-E594.

Long, C. L., Zikria, J. M., Kinney, J. M. \& Geiger, J. W. (1974). Comparison of fibrin hydrolysates and crystalline amino acid solutions in parenteral nutrition. American Journal of Clinical Nutrition 27, 163-174.

Lowry, M., Hall, D. E. \& Brosnan, J. T. (1985). Metabolism of glycine- and hydroxyproline-containing peptides by the isolated perfused rat kidney. Biochemical Journal 229, 545-549.

Lyster, R. L. J. (1972). Reviews of the progress of dairy science. C. Chemistry of milk proteins. Journal of Dairy Research 39, 279-318.

Maack, T., Johnson, V., Kau, S. T., Figueiredo, J. \& Sigulem, D. (1979). Renal filtration, transport, and metabolism of low-molecular-weight proteins: a review . Kidney International 16, 251-270.

MacFarlane, G. T. \& Allison, C. (1986). Utilisation of protein by human gut bacteria. FEMS Microbiology Ecology 38, 19-24.

MacFarlane, G. T., Cummings, J. H. \& Allison, C. (1986). Protein degradation by human intestinal bacteria. Journal of General Microbiology 132, 1647-1656.

McIntyre, P. B., Fitchew, M. \& Lennard-Jones, J. E. (1986). Patients with a high ileostomy do not need a special diet. Gastroenterology 91, 25-33.

Madden, S. C., Woods, R. R., Shull, F. W. \& Whipple, G. H. (1944). Amino acid mixtures effective parenterally 
for long continued plasma protein production. Casein digests compared. Journal of Experimental Medicine 79, 607-624.

Magnusson, I., Kihlberg, R., Eckman, L. \& Wahren, J. (1987b). Utilization of intravenously administered $N$ acetyl-L-glutamine in healthy man. Clinical Nutrition 6, Suppl., 31.

Magnusson, K., Alvestrand, A., Ekman, L. \& Wahren, J. (1987a). Protein and amino acid metabolism of skeletal muscle during starvation. Clinical Nutrition 6. Suppl., 62 Abstr.

Matoba, T. \& Hata, T. (1972). Relationship between bitterness of peptides and their chemical structures. Agricultural and Biological Chemistry 36, 1423-1431.

Matthews, D. M. (1975a). Intestinal absorption of peptides. Physiological Reviews 55, 537-608.

Matthews, D. M. (1975b). Absorption of peptides by mammalian intestine. In Peptide Transport in Protein Nutrition, pp. 61-146 [D. M. Matthews and J. W. Payne, editors]. Amsterdam: North-Holland Publishing Company.

Matthews, D. M. (1984). Absorption of peptides, amino acids and their methylated derivatives. In Aspartame: Physiology and Biochemistry, pp. 29-46 [L. D. Stegink and L. J. Filer, editors]. New York: Marce! Dekker Inc.

Matthews, D. M. \& Burston, D. (1983). Uptake of L-leucyl-L-leucine and glycylsarcosine by hamster jejunum in vitro. Clinical Science 65, 177-184.

Matthews, D. M. \& Burston, D. (1984a). Uptake of a series of neutral dipeptides including L-alanyl-L-alanine, glycylglycine and glycylsarcosine by hamster jejunum in vitro. Clinical Science 67, 541-549.

Matthews, D. M. \& Burston, D. (1984b). Absorption of proteins and their digestion products in early life. In Nutrition for Special Needs in Infancy: Protein Hydrolysates, pp. 13-22 [F. Lifshitz, editor]. New York: Marcel Dekker Inc.

Matthews, D. M. \& Payne, J. W. (1980). Transmembrane transport of small peptides. Current Topics In Membranes and Transport 14, $331-425$.

Miller, P. M., Burston, D., Brueton, M. J. \& Matthews, D. M. (1984). Kinetics of uptake of L-leucine and glycylsarcosine into normal and protein malnourished young rat jejunum. Pediatric Research 18, $504-508$.

Miyamoto, Y., Ganapathy, V., Barlas, A., Neubert, K., Barth, A. \& Leibach, F. H. (1987). Role of dipeptidyl peptidase IV in uptake of nitrogen from $\beta$-casomorphin in rabbit renal BBMV. American Journal of Physiology 252, F670-F677.

Moriarty, K. J., Hegarty, J. E., Fairclough, P. D., Kelly, M. J., Clark, M. L. \& Dawson, A. M. (1985). Relative nutritional value of whole protein, hydrolysed protein and free amino acids in man. Gut 26, $694-699$.

Neuhauser, M. (1985). Utilisation of glycyl-L-tyrosine during long-term parenteral nutrition in the rat. Clinical Nutrition 4, Suppl., 124-130.

Newsholme, E. A., Crabtree. B. \& Ardawi, M. S. M. (1985). Glutamine metabolism in lymphocytes: its biochemical, physiological and clinical importance. Quarterly Journal of Experimental Physiology 70, $473-489$.

Newsholme, E. A., Newsholme, P. \& Curi, R. (1987). The role of the citric acid cycle in cells of the immune system and its importance in sepsis, trauma and burns. In Krebs' Critic Acid Cycle: Half a century and still turning. Biochemical Society Symposium no. 54, pp. 145-161 [J. Kay and P. D. J. Weitzman, editors]. London: The Biochemical Society.

Ney, K. H. (1978). Bitterkeit und Gelpermeationschromatographie von enzymatischen Proteinhydrolysaten (Bitterness and gel-filtration chromatography of enzymic protein hydrolysates). Fette Seifen Anstrichmittel 80, 323-325.

Ney, K. H. (1979). Bitterness of peptides: Amino acid composition and chain length. In Food Taste Chemistry, ACS Symposium Series No. 115, pp. 149-173 [J. C. Boudreau, editor]. Washington, DC: American Chemical Society.

Nicholson, J. A. \& Peters, T. J. (1978). Subcellular distribution of hydrolase activities for glycine and leucine homopeptides in human jejunum. Clinical Science \& Molecular Medicine 54, 205- 207.

Nicholson, J. A. \& Peters, T. J. (1979). Subcellular localisation of peptidase activity in the human jejunum. European Journal of Clinical Investigation 9, 349-354.

Patel, D., Anderson, G. H. \& Jeejeebhoy, K. N. (1973). Amino acid adequacy of parenteral casein hydrolysate and oral cottage cheese in patients with gastrointestinal disease as measured by nitrogen balance and blood aminogram. Gastroenterology 65, 427-437.

Peterson, D. R., Oparil, S., Flourel, S. \& Carone, F. A. (1977). Handling of angiotensin II and oxytocin by renal tubular segments perfused in vitro. American Journal of Physiology 232, F319-324.

Petrilli, P., Pucci, P., Pelissier, J. P. \& Addeo, F. (1987). Digestion by pancreatic juice of a beta-casomorphincontaining fragment of buffalo beta-casein. International Journal of Peptide \& Protein Research 29, $504-508$.

Prockop, D. J., Keiser, H. R. \& Sjoerdsma, A. (1962). Gastrointestinal absorption and renal excretion of hydroxyproline peptides. Lancet ii, 527-528.

Puigserver, A., Chapus, C. \& Kerfelec, B. (1986). Pancreatic exopeptidases. In Molecular and Cellular Basis of Digestion, pp. 235-247 [P. Desnuelle, H. Sjöström and O. Norén, editors]. Amsterdam: Elsevier.

Rabkin, R. \& Kitaji, J. (1983). Renal metabolism of peptide hormones. Mineral \& Electrolyte Metabolism 9. 212-226.

Rajendran, V. M., Ansari, S. A., Harig, J. M., Adams, A. H. \& Ramaswamy, K. (1985). Transport of glycyl-Lproline by human intestinal brush border membrane vesicles. Gastroenterology 89, 1298-1304. 
Rees, R. G., Grimble, G. K., Halliday, D., Ford, C. \& Silk, D. B. A. (1988a). Influence of orally administered amino acids and peptides on protein turnover kinetics in the short bowel syndrome. Gut 29, Al397.

Rees, R. G.. Payne-James, J. J., Grimble, G. K. \& Silk, D. B. A. (1988 b). Requirement of peptides versus whole protein in patients with impaired gastrointestinal function : a double-blind controlled trial. Journal of Parenteral \& Enteral Nutrition 12, $12 S$.

Rees, R. G., Raimundo, A. H., Grimble, G. K., Hunjan, M. K. \& Silk, D. B. A. (1988c). Peptide based nitrogen source of enteral diets: studies with casein hydrolysates in man. Journal of Parenteral \& Enteral Nutrition 12. $21 S$.

Rennie, M. J. (1985). Muscle protein turnover and the wasting due to injury and disease. British Medical Bulletin 41, 257-264.

Rennie. M. J., Hundal, H. S., Babji, P., MacLennan, P., Taylor, P. M., Watt, P. W., Jepson, M. M. \& Millward, D. J. (1986). Characteristics of a glutamine carrier in skeletal muscle have important consequences for nitrogen loss in injury, infection and chronic disease. Lancet ii, 1008-1012.

Rerat, A., Simoes Nunes, C., Mendy, F. \& Roger, L. (1988). Amino acid absorption and production of pancreatic hormones in non-anaesthetized pigs after duodenal infusions of a milk enzymic hydrolysate or of free amino acids. British Journal of Nutrition 60, 121-136.

Robinson, A. B. \& Rudd, C. J. (1974). Deamidation of glutaminyl and asparaginyl residues in peptides and proteins. Current Topics in Cellular Regulation 8, 247-295.

Rolandelli, R. H., Koruda, M. J., Settle, R. G. \& Rombeau, J. L. (1986). The effect of enteral feedings supplemented with pectin in the healing of colonic anastomoses in the rat. Surgery 99, 703-707.

Roth, E., Karner, J., Ollenschlager, G., Karner, J., Simmel, A., Fürst, P. \& Funovics, J. (1988). Alanylglutamine reduces muscle loss of alanine and glutamine in post-operative anaesthetized dogs. Clinical Science 75, $641-648$.

Rothenbühler, E., Waibel, R.\& Solms, J. (1979). An improved method for the separation of peptides and $\alpha$-amino acids on copper Sephadex. Analytical Biochemistry 97, 367-375.

Rubino, A., Field, M. \& Schwachman, H. (1971). Intestinal transport of amino acid residues of dipeptides. I. Influx of the glycine residue of glycyl-L-proline across mucosal border. Journal of Biological Chemistry 246, 3542-3548.

Schlimme, E., Meisel, H. \& Frister H. (1989). Bioactive sequences in milk proteins. In Milk Proteins: Nutritional, Clinical, Functional and Technological Aspects, pp. 143-149 [C. A. Barth and E. Schlimme, editors]. Darmstadt: Steinkopff.

Semenza, G. \& Corcelli, A. (1986). The absorption of sugars and amino acids across the small intestine. In Molecular and Cellular Basis of Digestion, pp. 381-412 [P. Desnuelle, H. Sjöström and O. Norén, editors]. Amsterdam : Elsevier.

Silber, R. H. \& Porter, C. C. (1949). Urinary excretion of amino acids and peptides by dogs fed protein hydrolysates or amino acids. Journal of Nutrition 38, 155-164.

Silbernagl. S. (1977). Intratubular splitting of peptides and their reabsorption as single amino acids from the proximal convolution of rat kidney: a microperfusion study. Kidney International 11, 219.

Silbernagl, S. \& Volkl, H. (1977). The role of brush border enzymes in renal tubular transport of peptides, disaccharides and amino acids. Current Problems in Clinical Biochemistry 8, 59-65.

Silk, D. B. A. (1981) Peptide Transport. Clinical Science 60, 607-615.

Silk. D. B. A. (1989). Fibre and enteral nutrition. Gut 30, 246-264

Silk, D. B. A., Chung, Y. C., Berger, K. L., Conley, K., Sleisinger, M. H., Spiller, G. A. \& Kim, Y. S. (1979). Comparison of oral feeding of peptide and amino acid meals to normal human subjects. Gut 20, 291-299.

Silk, D. B. A., Fairclough, P. D., Clark, M. L., Hegarty, J. E., Marrs, T. C., Addison, J. M., Burston, D., Clegg, K. M. \& Matthews, D. M. (1980). Uses of a peptide rather than a free amino acid nitrogen source in chemically defined elemental diets. Journal of Parenteral \& Enteral Nutrition 4, 548-553.

Silk, D. B. A., Nicholson, J. A. \& Kim, Y. S. (1976). Relationships between mucosal hydrolysis and transport of two phenylalanine dipeptides. Gut 17, 870-876.

Smithson, K. W. \& Gray, G. M. (1977). Intestinal assimilation of a tetrapeptide in the rat. Obligate function of brush-border membrane aminopeptidases. Journal of Clinical Investigation 60, 665-674.

Song, I.-S., Yoshioko, M., Erickson, R. H., Miura, S., Guan, D. \& Kim, Y. S. (1986). Identification and characterisation of brush-order membrane-bound neutral metalloendopeptidases from rat small intestine. Gastroenterology $91,1234-1242$.

Souba, W. W., Scott, T. E. \& Wilmore, D. W. (1985). Intestinal consumption of intravenously administered fuels. Journal of Parenteral \& Enteral Nutrition 9, 18-22.

Stegink, L. D. \& Baker, G. L. (1971). Infusion of protein hydrolysates in the newborn infant : plasma amino acid concentrations. Journal of Pediatrics 78, 595-602.

Stchle, P. (1988). Bedarfsgerechte Bereitstellung von kurzkettigen Peptiden - Eine Voraussetzung für deren Einsatz in der kunstlichen Ernährung (Adequate provision of short chain peptides - A prerequisite for their use in clinical nutrition). Infusionstherapie 15, 27-32.

Stehle, P., Kuhne, B., Kubin, W., Fürst, P. \& Pfaender, P. (1982). Synthesis and characterisation of tyrosineand glutamine-containing peptides. Journal of Applied Biochemistry 4, 280-286.

Stehle, P., Pfaender, P.\& Fürst, P. (1984). Isotachophoretic analysis of a synthetic dipeptide :-alanyl-L-glutamine: evidence for stability during heat sterilisation. Journal of Chromatography 294, 507-512. 
Stehle, P., Zander, J., Mertes, N., Albers, S., Puchstein, Ch., Lawin, P. \& Fürst, P. (1989). Effect of parenteral glutamine peptide supplements on muscle glutamine loss and nitrogen balance after major surgery. Lancet $\mathbf{i}$, 231-233.

Steinhardt, H. J., Paleos, G. A., Brandl, M., Fekl, W. E. \& Adibi, S. A. (1984). Efficacy of a synthetic dipeptide mixture as the source of amino acids for total parenteral nutrition in a subhuman primate (baboon). Gastroenterology 86, 1562-1569.

Steinhardt, H. J., Wolf, A., Jakober, B., Schmuelling, R. M., Langer, K., Brandl, M., Fekl, W. E. \& Adibi, S. A. (1989). Nitrogen absorption in pancreatectomised patients: protein versus protein hydrolysate as substrate. Journal of Laboratory and Clinical Medicine 113, 162 . 167.

Sterchi, E. E. \& Woodley, J. F. (1980). Peptide hydrolases of the human small intestinal mucosa: identification of six distinct enzymes in the brush-border membrane. Clinica Chimica Acta 102, 57-65.

Stetler-Stevenson, M. A., Flouret, G. \& Peterson, D. R. (1981). Handling of luteinising hormone-releasing hormone by renal proximal tubular segments in vitro. American Journal of Physiology 241, F117-F122.

Tobey, N., Heizer, W., Yeh, R., Huang, T.-I. \& Hoffner, C. (1985). Human intestinal brush-border peptidases. Gastroenterology 88, 913-926.

Trocki, O., Mochizuki, H., Dominioni, L. \& Alexander, J. W. (1986). Intact protein versus free amino acids in the nutritional support of thermally injured animals. Journal of Parenteral \& Enteral Nutrition 10, $139-145$.

Tweedle, D. (1975). Intravenous amino acid solutions. British Journal of Hospital Medicine 13, 81-92.

Tweedle, D. E. F., Spivey, J. \& Johnston, I. D. A. (1973). Choice of intravenous amino acid solutions for use after surgical operation. Metabolism 22, 173-178.

Umetsu, H., Matsuoka, H. \& Ichishima, E. (1983). Debittering mechanism of bitter peptides from milk casein by wheat carboxypeptidase. Journal of Agricultural and Food Chemistry 31, 50-53.

US Pharmacopeia (1980). Protein hydrolysate injection. pp. 911-912.

Vasquez, J. A., Morse, E. L. \& Adibi, S. A. (1985). Effect of starvation on amino acid and peptide transport and peptide hydrolysis in humans. American Journal of Physiology 249, G563-G566.

Vinnars, E., Bergström, J. \& Fürst, P. (1974). Comparative nitrogen balance studies with an amino-acid solution based on nutritional studies against two protein-based solutions. Acta Anaesthesiologica Scandinavica 18. Suppl. no. 53, 76-80.

Vinnars, E., Fürst, P., Hallgren, B., Lill, I., Hermansson, J. L. \& Josephson, B. (1970). The nutritive effect in man of non-essential amino acids infused intravenously (together with the essential ones). I. Individual non-essential amino acids. Acta Anaesthesiologica Scandinavica 14, 147-172.

Vinnars, E., Fürst, P., Hermansson, J. L., Josephson, B. \& Lindholmer, B. (1969). Protein catabolism in the postoperative state and its treatment with amino acid solution. Acla Chirurgica Scandinavica 136, 95-109.

Walter, R., Simmons, W. H. \& Yoshimoto, T. (1980). Proline specific endo- and exopeptidases. Molecular \& Cellular Biochemistry 30, 111-127.

Wellner, D. \& Meister, A. (1981). A survey of inborn errors of amino acid metabolism and transport in man. Annual Review of Biochemistry 50, 911-968.

Wernerman, J., Hammarkvist, F., von der Decken, A. \& Vinnars, E. (1987). Ornithine-alpha-ketoglutarate improves skeletal muscle protein synthesis as assessed by ribosome analysis and nitrogen use after surgery. Annals of Surgery 206, 674-678.

Wilmore, D. W., Smith, R. J., O'Dwyer, S. T., Jacobs, D. O., Ziegler, T. R. \& Wang, X.-D. (1988). The gut: a central organ after surgical stress. Surgery 104, 917-923.

Windemueller, H. G. (1982). Glutamine utilisation by the small intestine. Advances in Enzymology 53, $201-238$.

Winters, R. W., Heird, W. C. \& Dell, R. B. (1984). History of parenteral nutrition in pediatrics with emphasis on amino acids. Federation Proceedings 43, 1407-1411.

Wood, S., Leenen, R., Pullicino, E. \& Elia, M. (1988). Effect of short-term starvation on the release of glutamine by human muscle. Proceedings of the Nutrition Society 47, 179A. 